\title{
Effects of Lavandula angustifolia Aroma on Electroencephalograms in Female Adults with Sleep Disorders
}

\author{
Hanna Jung ${ }^{1}$ and Hyunju Choi ${ }^{2}$ * \\ ${ }^{1}$ Department of Smart Foods and Drugs, ${ }^{2}$ Department of Biomedical Laboratory Science and Elderly Life Redesign Institute, Inje University, \\ Gimhae 621-749, Korea
}

Received December 3, 2011 / Revised January 17, 2012 / Accepted January 25, 2012

\begin{abstract}
This study investigated the effects of Lavandula angustifolia (L. angustifolia) aroma on the brain electrical activity evaluated by electroencephalogram (EEG) in female adults with sleep disorders. The subjects were 28 healthy female adults and their sleep disorders were classified by the Pittsburgh Sleep Quality Index. EEG electrodes were attached at the frontal (F3, F4), temporal (T3, T4), occipital (O1, $\mathrm{O} 2)$, parietal (P3, P4), reference, and ground regions according to the International 10-20 system. Subjects were exposed to the L. angustifolia aroma for $3 \mathrm{~min}$. Results showed that $L$. angustifolia aroma decreased the occipital and parietal alpha powers, and increased the frontal theta power and occipital beta power in subjects with good sleep quality. On the other hand, L. angustifolia aroma increased the theta power in the all cranial regions after aroma treatment in subjects with poor sleep quality. In conclusion, L. angustifolia aroma diminishes a state of wakefulness in the brain and helps individuals to fall asleep. Therefore, L. angustifolia aroma may have beneficial effect for female adults with sleep disorders.
\end{abstract}

Key words : EEG, Lavandula angustifolia, sleep disorder, PSQI

\section{서 론}

수면은 인간의 기본 욕구 중 하나로서 좋은 수면질을 유지 하는 것은 일상 생활을 건강하게 유지함에 있어서 중요하다. 2009년도 통계청 발표 자료에 의하면, 우리나라 8100개 표본 가구에 거주하는 10 24세의 청소년 4,628명을 대상으로 수면 실태를 분석한 결과, 고등학생의 $77 \%$ 가 수면 부족으로 피로감 에 시달리고 있다고 한다[32]. 미국의 경우 1,125 명 대학생을 대상으로 수면질을 조사한 결과에 의하면 $33 \%$ 이상이 나쁜 수면질을 갖고 있는 것으로 보고된 바 있다[26]. 20대 연령층의 수면 문제는 질병에 의한 것을 제외하고는, 주로 습관에 의한 경우가 많다고 알려져 있으며[22], 특히 대학생의 수면은 성별 에 영향을 받으며 여성일수록 수면 시간이 짧고 수면질이 떨 어진다는 연구 결과가 있었다 $[9,13]$.

라벤더(Lavandula angustifolia) 정유는 식물의 꽃에서 증기 증류법으로 추출한 것으로써 linalyl acetate와 linalool이 주 요 성분이며, linalool 성분은 CAMP를 증가시킴으로써 평활 근을 이완시키며 위장에 있는 가스가 배출되어서 통증을 경 감시킨다고 한다[25]. 한편, 동물실험에서 라벤더향을 흡입하 였을 때에 근육이 이완 되는 작용이 있음이 보고되었다[25]. 향기요법 중에서 라벤더향을 단독 또는 혼합하여 연구한 보 고를 살펴보면 스트레스를 호소하는 여성에서 스트레스가 감

*Corresponding author

Tel : +82-55-320-3665, Fax : +82-55-334-3426

E-mail : chj@inje.ac.kr
소하였다는 결과[23,30]와, 두통을 호소하는 중년 여성을 대상 으로 라벤더 혼합 오일을 처치하였더니 불안증이 감소되는 효과가 있었다고 보고된 바 있다[3]. 또한 수술 전에 불안해 하는 환자에게 손수건에 라벤더 오일을 떨어뜨려 20분간 향 을 맡게 하였더니 수술에 대한 불안 정도가 감소되었으며[8], 혈액 투석을 받는 여성 환자를 대상으로 라벤더 항기요법을 하였더니 우울 정도가 감소되었다[12]. 또한 중년여성을 대상 으로 1 주일간 라벤더향을 흡입하게 한 결과 우울한 감정이 감소되었을 뿐만 아니라 수면질이 증진됨을 주관적으로 느꼈 다는 연구 보고가 있다[16]. 이와 같이 라벤더향은 다양한 경 우의 사람에게서 우울한 감정을 감소시키고 긴장을 조절하는 효능이 있는 것으로 알려져 있다[1]. 라벤더향의 심리적인 효 과 외에도 피부 상처를 치료한다고 보고한 연구가 있는데, 만 성궤양을 가진 환자에게 라벤더 오일과 캐모마일 오일을 섞 어서 드레싱을 하였을 때 상처 회복에 도움이 되었다고 한다 [10]. 라벤더는 정유들 가운데 독성이 적으며 부작용이 거의 없다고 알려져 있어서[29], 피부 외상에도 사용되고 있는 것 이다.

향기요법에 대한 연구는 대부분 주관적인 척도에 의존하고 있는데 보다 타당한 객관적 검증이 필요하다고 사료된다. 뇌 기능적 검사는 뇌파 검사를 통해 객관적으로 판정 할 수 있다. 뇌파는 대뇌피질에 있는 신경세포가 발생하는 전기적 신호를 두피에서 측정하여 증폭하고, 시간의 흐름에 따라서 전위 변 화를 살펴봄으로써 뇌신경 활동을 측정한다[14]. 따라서 뇌파 
검사는 연속적으로 측정이 가능하고, 검사 방법이 비침습적이 라는 이점이 있다. 임상에서는 뇌파를 대부분 아날로그로 기 록된 신호를 이용하여 분석하지만, 이는 정량적인 자료로써의 제시가 어렵다는 문제가 있다. 본 실험에서는 Quantitative $\mathrm{EEG}(\mathrm{QEEG})$ 를 사용하여 정량적 분석을 시도함으로써 뇌기능 변화에 관한 객관적인 자료를 제시하고자 하였다. 따라서 본 연구는 라벤더 향기요법이 수면장애를 가지고 있는 젊은 연령 층의 사람에게 긍정적인 효과가 있는지에 대하여 살펴보고자 하는 목적으로, 라벤더향이 뇌기능에 미치는 효능을 뇌파 분 석을 통하여 알아보고자 하였다.

\section{재료 및 방법}

\section{연구 대상과 수면 장애 조사}

본 연구는 4 년제 대학교에 재학중인 여자 대학생 28 명을 대상으로 진행하였다. 나이, 키, 몸무게, 체지방 등의 일반적 특성에 대하여 체성분 분석기(InBody 3.0, BioSpace Co. Ltd., Korea)로 측정하고, 혈압과 맥박수를 측정하였다. 수면 장애가 있는 대상을 선별하기 위하여서는 Pittsburgh Sleep Quality Index (PSQI)를 사용하였다. PSQI는 수면장애를 감별하는 유 용한 척도로 가장 많이 이용되며 신뢰도와 타당성이 입증된 수면 설문지로써[2,18], 지난 1개월 동안에 주관적으로 느끼는 수면질, 수면 잠복시간, 수면 시간, 습관적 수면 효율, 수면 방해요인, 수면제 복용 여부, 낮 시간의 기능 장애가 있는가에 대한 총 7개 항목으로 수면장애를 평가한다. 본 연구에서는 PSQI에 의하여 수면질이 좋은 군(good sleep quality, GSQ) 15 명과 수면질이 나쁜 군(poor sleep quality, PSQ) 13명을 대 상으로 하였다.

\section{향기요법 및 뇌파 측정}

향기요법은 오후 1 시 부터 4 시 사이에 이루어졌으며, 환경 적 잡음을 제거하였고 실온과 습도를 적절하게 유지하였다. 피실험자에게 실험 과정에 관련하여 간단히 설명하여 침상에 눕게 하고 3 분간 눈을 감고 안정하도록 하였다. 그 후 라벤더 아로마 에센셜 오일 $50 \mathrm{ul}$ (Perfectpotion, Pty. Ltd, Australia) 을 고리 모양의 해면(넓이 $0.5 \mathrm{~cm}$, 직경 $3.5 \mathrm{~cm}$ )에 떨어뜨려서 피실험자가 코로 3 분간 흡입하도록 하였다.

피실험자에게 뇌파 측정 과정에 관련하여 간단히 설명을 한 후에 두피에 전극을 부착하여 침대에 눕게 한 후, 뇌파를 향기요법 처치 전, 중, 후 각 3 분씩 총 9 분 동안 측정하였다. 뇌파는 8-channel EEG system (LXE3208, LAXTHA Inc., Korea)로 측정하였으며, 전극은 International 10-20 electrode system을 이용하여 전두부(F3, F4), 측두부(T3, T4), 후 두부 $(\mathrm{O} 1, \mathrm{O} 2)$, 두정부(P3, P4)에 각각 두 개씩 부착하였고, 접지 전극은 왼쪽 귓볼(A1)에, 기준 전극은 오른쪽 귓볼(A2) 에 부착하였다. 샘플링 주파수는 $256 \mathrm{samples} / \mathrm{sec}$, 신호 수
집 감도는 $694.4 \mathrm{uV}$ 로 설정하였다. 뇌파 측정 신호는 $12 \mathrm{bit}$ $\mathrm{A} / \mathrm{D}$ 변환기를 통해 디지털 신호로 변환하여 수신기에 신호 를 전송하고 증폭하여 Telescan Program (LAXTHA Inc. Korea)을 이용하여, 델타파(delta wave, 0.5-3 Hz), 세타파 (theta wave, 3-8 Hz), 알파파(alpha wave, $8-13 \mathrm{~Hz}$ ), 베타파 (beta wave, $13-30 \mathrm{~Hz}$ ) 수치를 상대파워(relative power, $\mu \mathrm{V} /$ $\mu \mathrm{V})$ 로 표시하였다.

\section{통계 처리}

모든 데이터는 평균(mean)과 표준편차(SD)로 나타내었으 며 Student $t$-test를 사용하여 그륩간 유의성을 살펴 보았으며, $p<0.05$ 인 경우 통계적 유의성이 있는 것으로 간주 하였다. 그 룹 내의 뇌파 변동은 paired $t$-test를 이용하여 분석하였고 $p<0.05$ 인 경우 유의적 차이가 있는 것으로 하였다. 통계처리는 SPSS 17.0 을 이용하여 전산처리 하였다.

\section{결과와 고찰}

대상자의 일반적 특성, 혈압, 심박수

대상자의 일반적 특성으로서 나이, 몸무게, 키를 조사한 결과, 나이의 평균과 표준편차는 수면질이 좋은 군에서 $22.33 \pm 1.83$ 세, 키는 $161.26 \pm 5.35 \mathrm{~cm}$, 몸무게는 $53.72 \pm 5.66$ $\mathrm{kg}$ 이었고, 수면질이 나쁜 군에서는 $22.00 \pm 1.00$ 세, 키는 $160.00 \pm 5.05 \mathrm{~cm}$, 몸무게는 $54.94 \pm 6.22 \mathrm{~kg}$ 이었다. 나이, 몸무 게, 키에 있어서 수면질이 좋은 군과 나쁜 군 사이에 유의한 차이는 없었다. 체질량 지수(body mass index, $\mathrm{BMI}$ )의 평균 과 표준편차는 수면질이 좋은 군에서는 $20.68 \pm 2.13$ 이었고, 수면질이 나쁜 군에서는 $21.44 \pm 1.96$ 으로서 두 군 사이에 유 의적인 차이는 없었다.

수축기와 이완기 의 혈압과 심박수에 대한 결과는 Table 1 에 있다. 수면질이 나쁜 군에서 라벤더향에 의하여 수축기 혈압이 $117.0 \pm 16.2 \mathrm{mmHg}$ 에서 $106.0 \pm 7.1 \mathrm{mmHg}$ 으로 감소하 였다 $(p<0.05)$. 라벤더향에 의한 수축기 혈압 감소는 저혈압을 유발시키는 정도는 아니었고 정상 범위에 속하였다. 이는 고 등학교 배구선수를 대상으로 8주간 향기요법을 한 연구[13]와 대학생에게 향기요법을 한 연구[31]에서 수축기 혈압이 유의 하게 감소되었음을 보고한 것과 일치하는 결과로서, 흡입된 향기가 교감신경의 흥분을 감소시켜 신체적 이완을 가져온 결과라고 사료된다. 이완기 혈압은 수면질이 좋은 군과 나쁜 군, 모두에서 향기요법에 의한 변화가 없었다. 이는 수술을 받기 전날과 당일 수술 30 분 전 환자에게 라벤더와 버가못 오일을 5 분간 흡입한 후에 이완기 혈압에는 변화가 없었다는 결과[27]와 동일하나, 고등학교 배구선수를 대상으로 8주간 향 기요법을 한 연구[13]와는 상반되고 있다. 이는 향기를 흡입하 는 방법에서 기인된 것인지, 측정 방법상의 차이에서 기인된 것인지 반복 연구를 통하여 확인이 필요하다. 
Table 1. Blood pressure and pulse in subjects treated with lavender aroma

\begin{tabular}{|c|c|c|c|c|c|c|}
\hline \multirow[t]{2}{*}{ Group } & $\begin{array}{c}\text { Before aroma } \\
\text { treatment }\end{array}$ & $\begin{array}{c}\text { After aroma } \\
\text { treatment }\end{array}$ & $\begin{array}{c}\text { Before aroma } \\
\text { treatment }\end{array}$ & $\begin{array}{c}\text { After aroma } \\
\text { treatment }\end{array}$ & $\begin{array}{c}\text { Before aroma } \\
\text { treatment }\end{array}$ & $\begin{array}{c}\text { After aroma } \\
\text { treatment }\end{array}$ \\
\hline & Systolic BP & Systolic BP & Diastolic BP & Diastolic BP & Pulse & Pulse \\
\hline GSQ & $112.6 \pm 13.9$ & $115.0 \pm 15.7$ & $74.0 \pm 10.8$ & $76.2 \pm 13.1$ & $71.8 \pm 10.3$ & $66.8 \pm 7.5^{*}$ \\
\hline PSQ & $117.0 \pm 16.2$ & $106.0 \pm 7.1^{*}$ & $75.2 \pm 10.5$ & $72.2 \pm 4.0$ & $73.7 \pm 10.5$ & $70.2 \pm 10.1$ \\
\hline
\end{tabular}

All results are represented by mean \pm SD.

*: significant difference in the same line between values before and after aroma treatment $(p<0.05)$

GSQ: good sleep quality group $(n=15)$

PSQ: poor sleep quality group $(n=13)$

BP: blood pressure $(\mathrm{mmHg})$

한편 본 연구에서 라벤더향은 수면질이 좋은 군에서 심박수 를 $71.7 \pm 10.3$ 에서 $66.8 \pm 7.5$ 로 유의성 있게 감소시켰다 $(p<0.05)$. 이는 수술하기 전날과 당일 수술 30 분전 환자에게 라벤더와 버가못 오일을 5 분간 흡입시켰을 때 심박수가 감소하였다는 결과[27]와 동일하다.

\section{주관적 기분 상태}

주관적 기분 상태에서 가장 높은 점수는 10점으로써 가장 긴장한 상태이고, 0 점은 가장 낮은 점수로 이완된 상태를 의미 한다. 본 연구에서 라벤더향은 수면질이 좋은 군의 긴장 점수 를 $5.54 \pm 1.94$ 에서 $2.03 \pm 1.13$ 로 유의성이 있게 감소시켰고, 수면 질이 나쁜 군에서도 $6.53 \pm 2.00$ 에서 $2.65 \pm 1.41$ 로 유의성 있게 감소시켰다. 향기요법은 후각 신경을 통하여 그 효능이 나타 난다. 후각은 12 개 뇌신경(cranial nerve) 중에서 유일하게 외 부에 노출되어 있고 대뇌피질로 직접 투사하기 때문에 강력한 자극력을 가지며, 다양한 신체생리 작용을 조절하는 효과가 있다는 연구가 있다[7]. 본 연구의 결과는 라벤더 아로마 향기 요법을 적용한 경우 긴장감이 감소되고[7], 기질적 불안과 시 각적 상사 척도의 점수가 감소하며 $[21,28]$, 스트레스를 감소시
킨다는 연구 보고[19]와 유사하다.

\section{수면질이 좋은 군에서 향기요법에 의한 뇌파 변화}

수면질이 좋은 군에서 라벤더향이 뇌파에 미치는 결과를 살펴보면 왼쪽 대뇌의 모든 영역에서 델타파, 세타파, 베타 파의 변화가 없었다(Table 2). 그러나 알파파의 경우 후두부 에서 향기요법 전과 중을 비교하여 보면 $13.23 \%$ 가 감소하였 고, 향기요법 전과 후를 비교하여 보아도 $19.07 \%$ 가 감소하 였다(Fig. 1).

한편 오른쪽 대뇌에서 델타파는 변화를 보이지 않았다 (Table 3). 그러나 알파파의 경우 오른쪽 후두부에서 향기요법 전과 중에, 전과 후에는 각각 $8.81 \%, 23.30 \%$ 감소하였고, 두정 부에서도 알파파가 향기요법 전과 후에 $20.96 \%$ 감소하였다 (Fig. 2). 이는 라벤더향 1 분간 흡입시 전두엽과 오른쪽 측두엽 에서 알파파가 감소하였다는 결과[18]와 동일하다. 그러나 라 벤더 오일로 마사지를 한 후 알파파가 증가하였다는 연구가 있고[24], 라벤더향을 맡은 후에 알파파가 증가하였다는 연구 도 보고되어 있어서[11], 라벤더향이 알파파를 증가 또는 감소 시키는지에 대하여는 좀 더 연구가 필요하다고 사료된다. 한

Table 2. Effect of lavender aroma on the relative EEG powers from the left brain of the subjects with good sleep quality

\begin{tabular}{clccc}
\hline EEG wave & Cranial region & Before treatment & During treatment & After treatment \\
\hline \multirow{3}{*}{ Delta } & Frontal & $0.449 \pm 0.172$ & $0.421 \pm 0.203$ & $0.460 \pm 0.229$ \\
& Temporal & $0.456 \pm 0.171$ & $0.416 \pm 0.166$ & $0.482 \pm 0.217$ \\
& Occipital & $0.247 \pm 0.096$ & $0.275 \pm 0.129$ & $0.319 \pm 0.221$ \\
& Parietal & $0.288 \pm 0.103$ & $0.326 \pm 0.109$ & $0.361 \pm 0.239$ \\
\hline \multirow{3}{*}{ Theta } & Frontal & $0.188 \pm 0.088$ & $0.179 \pm 0.085$ & $0.207 \pm 0.110$ \\
& Temporal & $0.166 \pm 0.099$ & $0.171 \pm 0.091$ & $0.171 \pm 0.098$ \\
& Occipital & $0.117 \pm 0.078$ & $0.120 \pm 0.077$ & $0.130 \pm 0.098$ \\
& Parietal & $0.172 \pm 0.072$ & $0.168 \pm 0.072$ & $0.189 \pm 0.109$ \\
\hline \multirow{3}{*}{ Beta } & Frontal & $0.089 \pm 0.053$ & $0.097 \pm 0.045$ & $0.090 \pm 0.058$ \\
& Temporal & $0.112 \pm 0.082$ & $0.105 \pm 0.040$ & $0.103 \pm 0.062$ \\
& Occipital & $0.091 \pm 0.031$ & $0.107 \pm 0.047$ & $0.095 \pm 0.049$ \\
\hline
\end{tabular}

$\mathrm{N}=15$ female subjects

All results are represented by mean \pm SD.

There are no significant differences in the values of the same line. 




Fig. 1. Effect of lavender aroma on alpha powers from the left brain of the subjects with good sleep quality. *: significant difference between the bars of before aroma treatment and during aroma treatment $(p<0.05)$, **: significant difference between the bars of before aroma treatment and after aroma treatment $(p<0.05)$

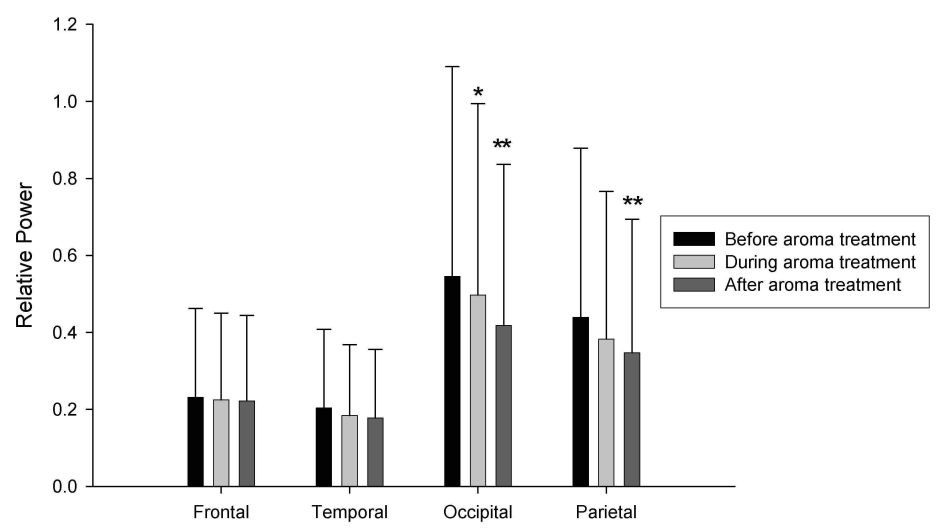

Fig. 2. Effect of lavender aroma on alpha powers from the right brain of the subjects with good sleep quality. *: significant difference between the bars of before aroma treatment and during aroma treatment $(p<0.05)$, **: significant difference between the bars of before aroma treatment and after aroma treatment $(p<0.05)$

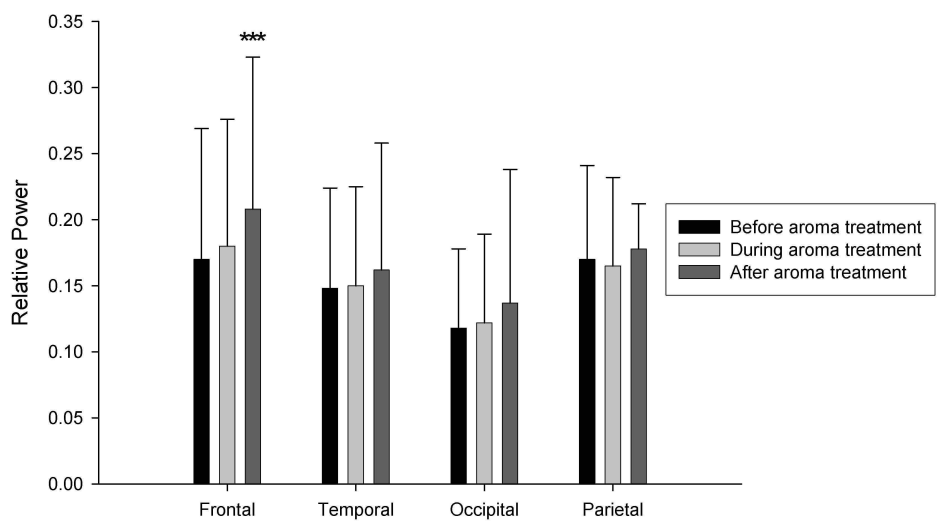

Fig. 3. Effect of lavender aroma on theta powers from the right brain of the subjects with good sleep quality. ${ }^{* * *}$ : significant difference between the bars of during aroma treatment and after aroma treatment $(p<0.05)$

편 본 연구에서 세타파는 오른쪽 대뇌 전두부에서 라벤더 향 기요법 중과 후를 비교할 적에 $15.56 \%$ 증가하였다(Fig. 3). 또 한 오른쪽 대뇌의 전두부에서 향기요법 중의 베타파가 향기요 법 전에 비하여 $13.98 \%$ 증가하였다(Table 3). 대학생을 대상으 로 연구한 타 논문에서도 라벤더향이 베타파를 증가시켰다고 하였다[6]. 본 연구 결과에서 라벤더향이 수면질이 좋은 여성 에게 있어서 안정된 각성시에 나타나는 알파파를 감소시키며 정신 집중을 할 때 주로 나타나는 베타파를 증가시키고, 또한 수면 초기에 나타나는 입면파인 세타파가 대뇌의 한부위에서
만 출현되고 있음을 볼 수 있었다.

\section{수면질이 나쁜 군에서 향기요법에 의한 뇌파 변화}

수면질이 나쁜 군에서 왼쪽 대뇌에서 델타파, 알파파, 베타 파는 향기요법에 의하여 유의적인 변화가 없었다(Table 4). 그 러나 세타파는 왼쪽 대뇌의 모든 부위에서 변화하였다. 즉 왼 쪽 대뇌의 전두부에서 향기요법 전과 후에 $37.95 \%$, 측두부에 서는 향기요법 전과 중, 향기요법 중과 후에 각각 $55.63 \%$, $39.87 \%$ 가 증가하였고, 후두부에서는 향기요법 전과 후에 
Table 3. Effect of lavender aroma on the relative EEG powers from the right brain of the subjects with good sleep quality

\begin{tabular}{clccc}
\hline EEG wave & Cranial region & Before treatment & During treatment & After treatment \\
\hline \multirow{3}{*}{ Delta } & Frontal & $0.472 \pm 0.200$ & $0.435 \pm 0.200$ & $0.423 \pm 0.196$ \\
& Temporal & $0.474 \pm 0.170$ & $0.462 \pm 0.170$ & $0.511 \pm 0.232$ \\
& Occipital & $0.219 \pm 0.123$ & $0.240 \pm 0.101$ & $0.331 \pm 0.258$ \\
& Parietal & $0.261 \pm 0.080$ & $0.310 \pm 0.122$ & $0.353 \pm 0.245$ \\
\hline \multirow{3}{*}{ Beta } & Frontal & $0.089 \pm 0.058$ & $0.097 \pm 0.059$ & $0.098 \pm 0.051$ \\
& Temporal & $0.112 \pm 0.052$ & $0.117 \pm 0.055$ & $0.101 \pm 0.063$ \\
& Occipital & $0.093 \pm 0.033$ & $0.106 \pm 0.038^{*}$ & $0.090 \pm 0.046$ \\
\hline
\end{tabular}

$\mathrm{N}=15$ female subjects

All results are represented by mean \pm SD.

*: significant difference between the bars of before aroma treatment and during aroma treatment $(p<0.05)$

Table 4. Effect of lavender aroma on the relative EEG powers from the left brain of the subjects with poor sleep quality

\begin{tabular}{clccc}
\hline EEG wave & Cranial region & Before treatment & During treatment & After treatment \\
\hline \multirow{3}{*}{ Delta } & Frontal & $0.494 \pm 0.182$ & $0.481 \pm 0.211$ & $0.466 \pm 0.207$ \\
& Temporal & $0.451 \pm 0.201$ & $0.437 \pm 0.209$ & $0.412 \pm 0.141$ \\
& Occipital & $0.396 \pm 0.202$ & $0.307 \pm 0.168$ & $0.336 \pm 0.150$ \\
& Parietal & $0.399 \pm 0.182$ & $0.366 \pm 0.141$ & $0.406 \pm 0.192$ \\
\hline \multirow{3}{*}{ Alpha } & Frontal & $0.170 \pm 0.120$ & $0.167 \pm 0.122$ & $0.166 \pm 0.128$ \\
& Temporal & $0.175 \pm 0.108$ & $0.165 \pm 0.118$ & $0.167 \pm 0.098$ \\
& Occipital & $0.314 \pm 0.175$ & $0.311 \pm 0.193$ & $0.276 \pm 0.156$ \\
& Parietal & $0.283 \pm 0.133$ & $0.236 \pm 0.127$ & $0.212 \pm 0.128$ \\
\hline \multirow{3}{*}{ Beta } & Frontal & $0.113 \pm 0.080$ & $0.104 \pm 0.052$ & $0.106 \pm 0.044$ \\
& Temporal & $0.155 \pm 0.087$ & $0.145 \pm 0.091$ & $0.139 \pm 0.066$ \\
& Occipital & $0.134 \pm 0.077$ & $0.153 \pm 0.062$ & $0.144 \pm 0.049$ \\
\hline
\end{tabular}

$\mathrm{N}=13$ female subjects

All results are represented by mean \pm SD.

There are no significant differences in the values of the same line.

$64.91 \%$ 가 증가하였으며 향기요법 중과 후에 $34.29 \%$ 증가하였 다. 또한 두정부에서는 향기요법 전과 중에 $27.33 \%$, 향기요법 전과 후에 $49.07 \%$ 가 증가하였다(Fig. 4). 따라서 왼쪽 대뇌에서 는 세타파가 전반적으로 $27 \sim 65 \%$ 증가한 것을 알 수 있었다.

한편 오른쪽 대뇌에서도 왼쪽 대뇌와 같이 향기요법에 의하 여 델타파, 알파파, 베타파의 변화가 없었다(Table 5). 그러나
세타파는 왼쪽 대뇌와 같이 오른쪽 대뇌에서도 모든 부위에서 증가하는 양상을 보였다(Fig. 5). 대뇌의 각 부위별로 살펴보 면, 전두부에서 향기요법 중과 후에 $27.32 \%$ 로 유의적인 증가 를 보였다. 이를 수면질이 좋은 군의 오른쪽 대뇌 전두부에서 향기요법에 따른 세타파의 변화가 없었던 결과와 비교하여 볼 적에 상이한 양상을 보였다. 한편 측두부에서는 향기요법

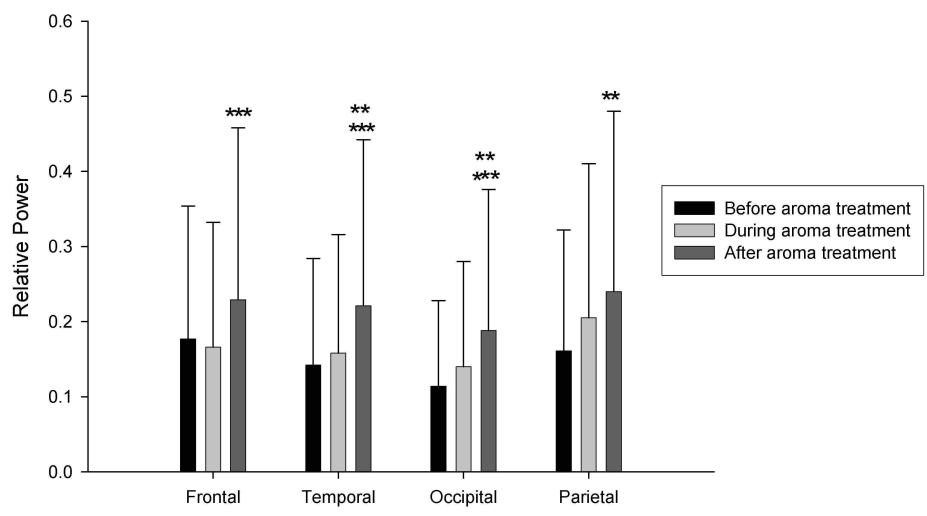

Fig. 4. Effect of lavender aroma on theta powers from the left brain of the subjects with poor sleep quality. ${ }^{* *}$ : significant difference between the bars of before aroma treatment and after aroma treatment $(p<0.05)$, ***: significant difference between the bars of during aroma treatment and after aroma treatment $(p<0.05)$ 
Table 5. Effect of lavender aroma on the relative EEG powers from the right brain of the subjects with poor sleep quality

\begin{tabular}{clccc}
\hline EEG wave & Cranial region & Before treatment & During treatment & After treatment \\
\hline \multirow{3}{*}{ Delta } & Frontal & $0.530 \pm 0.157$ & $0.493 \pm 0.184$ & $0.469 \pm 0.208$ \\
& Temporal & $0.508 \pm 0.168$ & $0.471 \pm 0.211$ & $0.471 \pm 0.155$ \\
& Occipital & $0.295 \pm 0.145$ & $0.295 \pm 0.202$ & $0.314 \pm 0.168$ \\
& Parietal & $0.379 \pm 0.156$ & $0.350 \pm 0.170$ & $0.400 \pm 0.162$ \\
\hline \multirow{3}{*}{ Alpha } & Frontal & $0.173 \pm 0.113$ & $0.179 \pm 0.116$ & $0.169 \pm 0.123$ \\
& Temporal & $0.164 \pm 0.087$ & $0.153 \pm 0.092$ & $0.147 \pm 0.080$ \\
& Occipital & $0.444 \pm 0.177$ & $0.406 \pm 0.225$ & $0.350 \pm 0.189$ \\
& Parietal & $0.267 \pm 0.138$ & $0.239 \pm 0.145$ & $0.216 \pm 0.133$ \\
\hline \multirow{3}{*}{ Beta } & Frontal & $0.095 \pm 0.059$ & $0.101 \pm 0.054$ & $0.100 \pm 0.051$ \\
& Temporal & $0.129 \pm 0.064$ & $0.125 \pm 0.072$ & $0.117 \pm 0.057$ \\
& Occipital & $0.122 \pm 0.066$ & $0.122 \pm 0.062$ & $0.124 \pm 0.056$ \\
\hline
\end{tabular}

$\mathrm{N}=13$ female subjects

All results are represented by mean \pm SD.

There are no significant differences in the values of the same line.

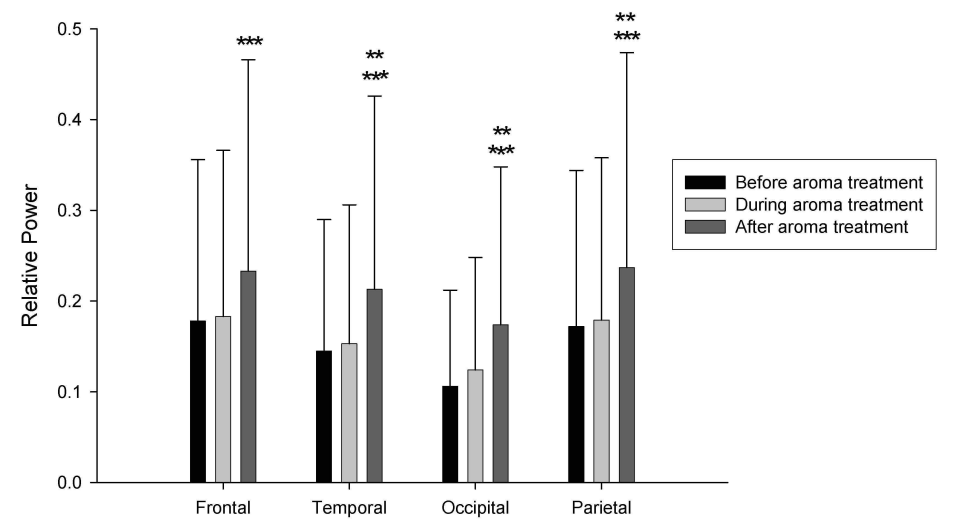

Fig. 5. Effect of lavender aroma on theta powers from the right brain of the subjects with poor sleep quality. **: significant difference between the bars of before aroma treatment and after aroma treatment $(p<0.05)$, ${ }^{* *}$ : significant difference between the bars of during aroma treatment and after aroma treatment $(p<0.05)$

전과 후, 향기요법 중과 후에 각각 $46.90 \%, 39.22 \%$ 가 증가하였 다. 후두부에서 향기요법 전과 후에 $64.15 \%$ 증가하였고, 향기 요법 중과 후에 $40.32 \%$ 증가하였다. 두정부에서는 향기요법 전과 후에 $37.79 \%$ 증가하였고, 향기요법 중과 후에 $32.40 \%$ 증 가하였다 따라서 오른쪽 대뇌에서는 왼쪽 대뇌와 유사하게 세타파가 전반적으로 27 65\% 증가한 것을 알 수 있었다. 세타 파의 경우 깊이 내면화되고 조용한 상태의 육체, 감정 및 사고 활동과 관계된 파형으로써 수면에 있어서 입면기에 세타파가 증가하는 것으로 알려져 있다[15].

라벤더향이 수면질에 미치는 타 연구를 살펴보면, 45 55 세 중년 여성이 일주일에 20분씩 2회, 총 12주 동안 라벤더 향을 맡은 후에 수면질이 향상되었다는 연구가 있다[4]. 한 편, 라벤더를 클라리 세이지, 마조람, 진저와 혼합한 아로마 블렌딩 오일로 골관절염이 있는 노인 여성의 다리 부위를 마사지하였더니 수면장애가 감소하였다고 한다[5]. 반면 중 년기 여성을 대상으로 라벤더 오일을 2주간 처치한 후, 주관 적으로 감지하는 수면질과 우울감은 감소하였으나, 총 수면 시간, 입면시간, 수면 중 각성횟수, 기상하였을 때에 느끼는
휴식감에 대해서는 유의한 영향을 미치지 않았다는 연구가 있었다[20].

본 연구의 결과를 요약하면 신체적으로 건강한 20대 여자 성인을 대상으로 검증된 수면장애 조사를 통하여 수면질을 조사하여 수면 문제를 가진 대상자를 선별하고 라벤더 향기요 법을 실행하여 뇌파 변화를 분석하였다. 라벤더향이 뇌파에 미치는 영향은 수면질이 좋은 여성에서 후두부와 두정부에서 알파파를 감소시키는 반면, 전두부에서 세타파와 후두부에서 베타파를 증가시키는 것으로 나타났다. 그러나 수면질이 나쁜 여성의 경우, 라벤더향은 대뇌의 모든 영역에서 수면 입면파 인 세타파를 증가시켰다. 따라서 라벤더 향기요법은 수면질이 나쁜 여성에게 수면을 유도하는 긍정적인 뇌기능 효능이 있음 을 확인하였다.

\section{감사의 글}

본 연구는 한국연구재단 일반연구자지원사업(2011-0006026) 에 의하여 일부 지원을 받아서 수행하였습니다. 


\section{References}

1. Buckle, J. 2007. Literature review: should nursing take aromatherapy more seriously? Br. J. Nurs. 16, 116-120.

2. Buysse, D. J., C. F. Reynolds, T. H. Monk, S. R. Berman, and D. J. Kupfer. 1989. The Pittsburgh Sleep Quality Index: a new instument for psychiatric practice and research. Psychiatry Res. 28, 193-213.

3. Cha, J. H., M. J. Kim, H. S. Kim, and Y. I. Kim. 2010. Effects of aromatherapy in blending oil of basil, lavender, rosemary, and rose on headache, anxiety and serum cortisol level in the middle-aged women. J. Korean Biol. Nurs. Sci. 12, 133-139.

4. Chein, L. W., S. L. Cheng, and C. F. Liu. 2011. The effect on lavender aromatherapy on autonomic nervous system in midlife women with insomnia. Evid Based Complement. Alternat. Med 2011, 1.

5. Choi, I. R. 2006. Effects of aromatherapy massage on pain, physical function, sleep disturbance and depression in elderly women with osteoarthritis. Korea. J. Women Health Nurs. $12,168-176$

6. Diego, M. A., N. A. Jones, T. Field, M. Hernandez-Reif, S. Schanberg, C. Kuhn, V. McAdam, R. Galamaga, and M. Galamaga. 1998. Aromatherapy positively affects mood, EEG patterns of alertness and math computations. Intern. J. Neurosci. 96, 217-224.

7. Edge, J. 2003. A pilot study addressing the effect of aromatherapy massage on mood, anxiety and relaxation in adult mental health. Complement. Ther. Nurs. Midwifery 9, 90-97.

8. Fayazi, S., M. Babashahi, and M. Rezaei. 2011. The effect of inhalation aromatherapy on anxiety level of the patients in preoperative period. Original Article 16, 1-6.

9. Han, S. H. 2008. Effects of aromatherapy on headache, stress and immune response of students with tension-type headache. J. Korean Acad Soc. Nurs. Edu. 14, 273-281.

10. Hartman, D. and J. Coetzee. Two US practitioner's experiences of using essential oils for wound care. J. Wound Care 2002. 11, 317-320.

11. Hongratanaworakit, T. 2004. Physiological effects in aromatherapy. Songklanalarin J. Sci. Technol. 26, 117-125.

12. Itai, T., H. Amayasu, M. Kuribayashi, N. Kawamura, M. Okada, A. Momose, T. Tateyama, K. Narumi, W. Uematsu, and S. Kaneko. 2000. Psychological effects of aromatherapy on chronic hemodialysis patients. Psychiatry Clin. Neurosci. 54, 393-397.

13. Ju, K. Y. 2007. The effect of aromatherapy psychological stress and stress hormones in blood after maximal exercise. Korean Soc.Beauty Industry. 2, 147-164.

14. Kim, D. S., B. W. Kim, Y. H. Kim, J. K. Kim, B. H. Min, H. J. Bae, S. O. Song, J. S. Yoon, O. K. Lee, S. H. Jung, S. C. Choi, W. S. Choi, and H. J. Choi. 2006. Clinical Physiology. Koreambp. 327-330.

15. Kim, D. S., B. W. Kim, Y. H. Kim, J. K. Kim, B. H. Min, H. J. Bae, S. O. Song, J. S. Yoon, O. K. Lee, S. H. Jung, S. C. Choi, W. S. Choi, and H. J. Choi. 2006. Clinical Physidogy Koreambp. 396-406.
16. Kim, H. K., H. G. Kim, Y. S. Cheong, E. W. Park, and S M. Yoo. 2001. The effect of aromatherapy on dysmenorrhea from high school girls. J. Korean Acad Fam Med 22, 922-929.

17. Knutson, K. L., P. J. Rathouz, L. L. Yan, K. Liu, and D. S. Lauderdale. 2006. Stability of the Pittsburgh Sleep Quality Index and the Epworth Sleepiness Questionnaires over 1 year in early middle-aged adults: The CARDIA study. Sleep. 29, 1503-1506.

18. Lee, D. and J. Lee. 2003. A study on the physiological change of EEG by olfactory stimulation. Korean J. Sci. Emot. Sens. 6, 29-35.

19. Lee, H. S. 2008. The effects of aroma inhalation on nursing students' stress response and anxiety before their first clinical practice. J. Korean Acad Comm Health Nurs. 19, 112-119.

20. Lee, K. H., K. M. Park, and M. K. Ryu. 2002. The effect of aromatherapy with lavender essential oil on sleep disturbance and depression on middle-aged women. J. Korean Soc. Matern. Child Health 6, 23-37.

21. Lee, S. H. 2001. Effects of back massage with lavender essence oil on the stress response of the ICU nurses. J. Korean Acad Nurs. 31, 770-780.

22. Lee, W. J., and H. J. Choi. 2011. Sleep behavior and sleep disorder characteristics in college students. Inje NonChong. 26, 289-306.

23. Lee, Y. H. 2008. The effectiveness of back massage using aromatherapy in reducing physical and psychological stress. The Korea Acad Indus. Coop. Soc. 9, 246-256.

24. Lindsay, R., J. Tohme, and B. Kanders. 1986. The effect of oral contraceptive use on vertebral bone mass in pre-and post-menopausal women. Contraception 34, 333-340.

25. Lis-Balchin, M. and S. Hart. 1999. Studies on the mode of action of the essential oil of lavender (Lavandula angustifolia P. Miller). Phytother. Res. 13, 540-542.

26. Lund, H. G., B. D. Reider, A. B. Whiting, and J. R. Prichard. 2010. Sleep patterns and predictors of disturbed sleep in a large population of college students. J. Adolesc. Health 46, 124-132.

27. Oh, J. N., H. J. Kim, and J. H. Park. 2008. Effect of aroma therapy on the anxiety, blood pressure and pulse of uterine leiomyoma patients before surgery. Korean J. Women Health Nurs. 14, 28-35.

28. Oh, Y. H. 2006. The effects of inhalation method using essential oils on the preoperative anxiety of hysterectomy patients. Korean Soc. Nurs. Sci. 36, 1123-1134.

29. Robins, J. L. W. 1999. The science and art of aromatherapy. J. Holist. Nurs. 17, 5-17.

30. Seo, H. K. and K. S. Park. 2003. A study on the effects of aroma inhalation method using clarysage essential oil on stress in middle-aged women. Korean Soc. Women Health Nurs. 9, 70-79.

31. Son, K. C., J. E. Song, S. J. Um, K. Y. Paek, H. K. Oh, J. S. Lee, and J. H. Kim. 2001. Effect of absorption of essential oils on the changes of arousal and antistress. J. Korean Soc. Horticul. Sci. 42, 614-620.

32. Statistics Korea. http://www.kostat.go.kr. 


\section{초록 : 라벤더향이 수면장애가 있는 여자 성인의 뇌파에 미치는 영향}

\section{정한나 ${ }^{1} \cdot$ 최현주 $^{2}{ }^{*}$}

(인제대학교 ${ }^{1}$ 식의약생명 공학과, ${ }^{2}$ 임상병리학과, 고령자라이프리디자인연구소)

본 연구는 라벤더(Lavandula angustifolia)향이 뇌기능에 미치는 효능을 객관적인 관점에서 살펴보고자 함에 의 의를 두고 뇌파 변화를 살펴보았다. 신체적으로 건강한 20대 여자 성인(28명)을 대상으로 검증된 수면장애 조사 를 통하여 수면질을 조사하여 수면에 문제를 가진 대상자를 선별하고 라벤더 향기요법을 실행하여 뇌파의 변화 를 분석하였다. 뇌파 전극은 10-20 국제법에 의하여 전부두(F3, F4), 측두부(T3, T4), 후두부(O1, O2), 두정부(P3, P4)에 부착하였다. 향기요법을 시행하기 전 3 분, 시행 중 3 분, 그리고 시행 후 3 분씩 나누어서 뇌파 검사를 시행하 였다. 라벤더향은 수면질이 좋은 사람(15명)에서 후두부와 두정부에서 알파파를 감소시키고, 전두부에서는 세타 파와 후두부에서 베타파를 증가시켰다. 그러나 수면질이 나쁜 사람(13명)에서는 대뇌 모든 영역에서 수면 입면파 인 세타파만을 증가시키는 효능이 나타났다. 따라서 라벤더향은 수면질이 나쁜 사람에게 수면을 유도하는 긍정 적인 뇌기능 효능이 있음을 확인하였다. 